\title{
Transposition
}

Musique et Sciences Sociales

$7 \mid 2018$

Le prix de la musique

\section{Marina Frolova-Walker, Stalin's Music Prize: Soviet Culture and Politics}

New Haven/London, Yale University Press, 2016.

\section{Simo Mikkonen}

\section{OpenEdition}

\section{Journals}

Electronic version

URL: http://journals.openedition.org/transposition/2339

DOI: 10.4000/transposition.2339

ISSN: 2110-6134

Publisher

CRAL - Centre de recherche sur les arts et le langage

\section{Electronic reference}

Simo Mikkonen, « Marina Frolova-Walker, Stalin's Music Prize: Soviet Culture and Politics », Transposition [Online], 7 | 2018, Online since 15 September 2018, connection on 25 September 2020. URL : http:// journals.openedition.org/transposition/2339; DOI : https://doi.org/10.4000/transposition.2339

This text was automatically generated on 25 September 2020 .

La revue Transposition est mise à disposition selon les termes de la Licence Creative Commons Attribution - Partage dans les Mêmes Conditions 4.0 International. 


\title{
Marina Frolova-Walker, Stalin's Music Prize: Soviet Culture and Politics
}

New Haven/London, Yale University Press, 2016.

\author{
Simo Mikkonen
}

\section{REFERENCES}

Marina Frolova-Walker, Stalin's Music Prize: Soviet Culture and Politics, New Haven/ London, Yale University Press, 2016.

1 Although the title and the cover of Stalin's Music Prize: Soviet Culture and Politics might suggest otherwise, make no mistake: this is not a book about Stalin. Although he remains an obsession in popular literature on Soviet music, scholars mostly use Stalin as a marketing gimmick. Yet, the cover featuring Vitaly Komar and Alexander Melamid's painting The Origins of Socialist Realism, combining Dadaist art with socialist realism, was not chosen haphazardly. Even if one of Marina Frolova-Walker's key arguments is that Stalin was not especially active in nominating laureates, the Stalin prizes exerted significant influence on the guidelines for late-Stalinist musical policies. The sought-after Stalin prizes conveyed major financial benefits and prestige, directing the creative activities of composers and performers. Despite the somewhat dull title, the book is much more than Stalin's music prize.

2 The book is gracefully written and generally makes for compelling reading. While the focus is on the Stalin prize committee, how it emerged and worked, who its key members were and so on, Frolova-Walker essentially tells a story about power relations in a society under a dictatorship. The Stalin prize committee was a source of power that influenced Soviet cultural life much more deeply than merely handing out honours. Here, Frolova-Walker makes another important contribution to the study of Soviet music history - she discusses in detail the roles of composers little known in the West today. Nikolai Myaskovsky, Yuri Shaporin, Alexander Goldenweizer and Reinhold Glière, in particular, were towering figures in Soviet musical life through both their 
compositions and teaching and their roles in the Soviet cultural administration. However, their music is rarely played today, even in Russia, and elsewhere, they are almost forgotten. Prokofiev and Shostakovich have become such dominant figures that their roles in the Stalinist era can easily be exaggerated.

The Stalin prize committee's decisions prompted important aesthetic and political discussions concerning music. Importantly, it was not Stalin or his henchmen who were the major players behind these discussions. Artists themselves formed the Stalin prize committee. In music, composers and music professionals were behind most decisions. The prevalent myth about Stalin-era music guided and controlled by Stalin and his closest associates - which scholarship has already challenged - does not withstand Frolova-Walker's strongly argued case: music professionals had major roles in shaping Stalin-era music politics. As part of the Soviet elite, they acted accordingly, defending their positions and benefiting their own area of the arts - music. Although FrolovaWalker introduces several important but little-known composers, she also gives much room for Shostakovich. Her book presents not passive, reserved composers but active, engaged advocates, willingly participating in debates with political undertones.

The book is extremely valuable for any scholar working on Soviet music. Moreover, Frolova-Walker puts her rich, insightful description of how the Stalin prize committee operated in a wider context, making the book an important reading for wider audiences. Comparing music with the other arts and placing the committee within the larger body of Soviet administration, the book reveals the intricacies of the Stalinist bureaucracy and the power relations of a communist dictatorship, which have meaning well beyond music in the late Stalin era.

Frolova-Walker concludes that although coloured by personal tastes and sometimes politics and ideology, decisions on Stalin prizes in music were mostly based on aesthetic reasoning. This might disappoint those who like to see the late Stalinist era as the epitome of a monolithic dictatorship in which Stalin made all the important decisions. Even in dictatorships, though, power is inevitably distributed to lower levels and to more people than might seem at a first glance. Drawing on a vast pool of littleused or unused primary source materials, Frolova-Walker manages to build a colourful picture of the workings of the Stalin prize committee. She skilfully uses letters, diaries, reports and committee transcripts, making these sources of information transparent to readers. Few scholars manage to contextualise their sources in such a way that readability does not suffer. Stalin's Music Prize is an engaging and rigorously researched work that manages to breathe fresh air into the study of the late Stalin era and to provide new knowledge about the workings of the Soviet power structures, particularly - but not only - in the field of arts and culture. 


\section{AUTHORS}

\section{SIMO MIKKONEN}

Simo Mikkonen is Academy of Finland Research Fellow at the Department of History and Ethnology, University of Jyväskylä (Finland). He is specialized in 20th Century Russian and Eastern European history, cultural and artistic diplomacy, and émigrés. He has published extensively on cultural, international and transnational East-West connections, particularly from the Soviet perspective, including a monograph State Composers and the Red Courtiers. Music, Ideology and Politics in the Soviet 1930s (Mellen 2009), and edited volumes Beyond the Curtain: Entangled Histories of the Cold War-Era Europe (Berghahn 2015), as well as Music, Art, and Diplomacy: East-West Cultural Interactions and the Cold War (Routledge 2016). Forthcoming in October 2018 is an edited volume Entangled East and West. Cultural Diplomacy and Artistic Interaction during the Cold War (Degruyter 2018) and monograph Networking the Russian Diaspora: Russian Musicians and Musical Activities in Interwar Shanghai together with Hon-Lun Yang and John Winzenburg (Hawaii UP 2018). 